\title{
Faith Binckes, Kathryn Laing, Hannah Lynch (1859-1904): Irish Writer, Cosmopolitan, New Woman
}

\section{Orsolya Szücs}

\section{(2) OpenEdition}

1 Journals

\section{Édition électronique}

URL : https://journals.openedition.org/etudesirlandaises/10422

DOI : $10.4000 /$ etudesirlandaises. 10422

ISSN : 2259-8863

\section{Éditeur}

Presses universitaires de Caen

\section{Édition imprimée}

Date de publication : 31 décembre 2020

Pagination : 210-213

ISBN : 978-2-84133-996-9

ISSN : 0183-973X

\section{Référence électronique}

Orsolya Szücs, « Faith Binckes, Kathryn Laing, Hannah Lynch (1859-1904): Irish Writer, Cosmopolitan, New Woman », Études irlandaises [En ligne], 45-2 | 2020, mis en ligne le 31 décembre 2020, consulté le 16 novembre 2022. URL : http://journals.openedition.org/etudesirlandaises/10422 ; DOI : https:// doi.org/10.4000/etudesirlandaises. 10422

\section{(c) (i) (2) (2)}

Creative Commons - Attribution - Pas d'Utilisation Commerciale - Partage dans les Mêmes Conditions 4.0 International - CC BY-NC-SA 4.0

https://creativecommons.org/licenses/by-nc-sa/4.0/ 
Dans les deux essais qui suivent, signés respectivement par John McCourt et Paul Fagan, il est question des rapports entre Behan et deux figures majeures de la littérature irlandaise: James Joyce et Brian O’Nolan. Le premier s'appuie sur le texte d'une conférence donnée par Behan à New York en 1962 pour «explorer l'importante influence de Joyce sur Behan tant dans son rôle de chroniqueur de Dublin que d'auteur moderniste» (p. 12). Fagan, quant à lui, analyse la manière dont O’Nolan présente Behan, le personnage, dans les chroniques écrites sous le pseudonyme de Myles na Gopaleen dans les années 1950.

Pour terminer, Michael Pierse s'attaque à la dernière pièce de Behan, Richard's Cork Leg. Pierse est courageux car, comme pour d'autres textes de Behan, l'approche critique est problématique, la pièce ayant été reconstituée par Alan Simpson à partir des notes écrites par Behan entre décembre 1960 et juin 1961. Cette dernière contribution est peut-être la plus intéressante dans ce qu'elle soulève comme interrogation. Comment recevoir les derniers textes de Behan, incomplets ou altérés par l'intervention d'un tiers, mais qui peuvent apporter des clés nouvelles pour une plus ample compréhension de l'auteur?

McCourt le dit en introduction, beaucoup reste à dire sur Behan (p. 2) et cet ouvrage, à lui seul, ne pourrait combler le vide. Il est néanmoins inspirant et on y trouve aussi une bibliographie complète. La promesse de l'éditeur d'apporter une lumière nouvelle sur le travail de Behan est tenue, et nous partageons avec McCourt l'espoir qu'il puisse montrer le chemin et susciter un regain d'intérêt de la part de la critique (p. 14).

Chiara Rustici

Faith Binckes, Kathryn Laing, Hannah Lynch (1859-1904): Irish Writer, Cosmopolitan, New Woman, Cork, Cork University Press, 2019, xii + 248 p.

The recent decade in Irish literature has been marked by a boom in critical research that seeks to restore fairness to the canon's gender inequality. Although there is always a risk of exclusion, in the case of Ireland, women writers have suffered from a serious degree of under-representation in Irish critical discourse. The change is detectable by a new wave of inspiring critics who challenge previous traditions, showing the cultural richness of female presences in Irish literary history.

The late $19^{\text {th }} /$ early $20^{\text {th }}$ century was a crucial period in Ireland, marking the beginning of the free Irish State and the nation's cultural revival. However, as contemporary scholarly research shows, it was also a prosperous period of Irish-born women writers who actively participated in the re-formation of the nation. The long line of recent critical studies reflecting on this female literary achievement includes 
works like Tina O'Toole's The Irish New Woman (Basingstoke, Palgrave Macmillan, 2013); Lauren Arrington's Revolutionary Lives: Constance and Casimir Markiewicz (Princeton, Princeton University Press, 2015); Anne Jamison's E. E. Somerville and Martin Ross: Female Authorship and Literary Collaboration (Cork, Cork University Press, 2016); Eglantina Remport's Lady Gregory and Irish National Theatre: Art, Drama, Politics (Basingstoke, Palgrave Macmillan, 2018); Catherine Morris's Alice Milligan and the Irish Cultural Revival (Dublin, Four Courts Press, 2012); and Irish Women's Writing, 1878-1922: Advancing the Cause of Liberty, Anna Pilz and Whitney Standlee (eds.) (Manchester, Manchester University Press, 2016). Not only do these studies shed light on forgotten voices, but they also prove the existence of a continuum of the strong female presence in modern Irish literary and political history.

This current critical context is what makes Faith Binckes' and Kathryn Laing's comprehensive study on Hannah Lynch, the $19^{\text {th }}$-century feminist writer, journalist, and political activist, very timely and important. The work is entitled Hannah Lynch (1859-1904): Irish Writer, Cosmopolitan, New Woman, published by Cork University Press in 2019. It is the result of years of meticulous research across libraries and countries. The two authors have clearly set out to re-canonise and to re-introduce this writer into the current of Irish literary history and criticism. The reader is provided with details of various international connections as well as political and historical events that cast a new, astonishing perspective on the dynamics of fin-de-siècle literature. It is not only a book on Hannah Lynch but a triggering study of transnational networks at the end of the $19^{\text {th }}$ century. The language of the book is written in an accessible style, comprehensible to a wide range of readers. It guides us through the chronology of Lynch's life in a coherent analysis that maintains a serious critical perspective. It is rich in authentic passages: reviews, personal correspondences, and various documents of the time that are harmoniously inserted into the study of this long-forgotten writer's oeuvre. One of the main strengths of the book is that this complex, almost documentary-like structure does not create an anachronistic impression. Lynch was a forerunner of her age, seen as provocative by her contemporaries but as a revolutionary figure in our time. But who is Hannah Lynch?

Although she has lived during the period of the Irish political and cultural revival and met most of the well-known figures, her life has been left overlooked for many years. Lynch was supportive of the nationalist ideologies, having spent her childhood in Dublin, in a family that was greatly involved in contemporary politics. Her stepfather, James Cantwell, was a high profile Dublin figure of the time. He was involved in the 1848 rebellion, and he was part of the Fenian movement. Lynch's sisters eleven altogether and her mother played an active role in the Ladies Land League between 1881 and its dissolution in 1882. Hannah herself was the London Secretary of the League, an organisation that, although lasting for a very short time, had played a crucial role in shaping a new, active agency and role for Victorian women. Lynch was acquainted from an early age with representative voices of the age, but she also received a complex education, having studied in England and France. The writers imply that these experiences have shaped Lynch's individualistic 
nationalist views. She was an anti-imperialist, but this did not prevent her from being outspokenly critical of the hypocrisies of the Catholic Church.

Lynch published reviews in the newspaper United Ireland, including some on Oscar Wilde's plays. She has also met Wilde in person at Lady Wilde's London home. She wrote critical studies in Dublin for the Freeman's Journal and the Irish Monthly, but her work also appeared in London in well-established journals like Murray's Magazine and MacMillan's Magazine. Her most lengthy involvement was with the London periodical entitled Academy: she was the Paris correspondent until the end of her life. She wrote on various topics, including the feminist question, the nationalist cause, anti-semitism, and even the Dreyfus Affair, in which she fiercely defended Alfred Dreyfus.

Faith Binckes' and Kathryn Laing's critical study gives the readers direct access to the intricacies and various connections of Lynch's life with a rich analysis of her works. The book has a chronological structure, but it also creates a thematic portrayal of the topics present in Lynch's oeuvre. The first two chapters discuss the 1880s, with details on her childhood and early writings. The authentic accounts of Lynch from various contemporaries and her personal correspondences depict an important period of Irish history itself. The strength of these chapters lies in their extensive account of emerging nationalist networks, showing the vital role that feminist organisations played in the birth of what is today known as the Irish Literary Revival. From this perspective, the book presents a very different face of the movement to that presented previously in Irish criticism. Another crucial publication by Eglantina Remport, Lady Gregory and Irish National Theatre: Art, Drama, Politics might almost be seen as a complement to parts of Binckes' and Laing's study. Remport focuses on Lady Gregory, but also unearths a previously hidden picture of the early Revivalist movement and its female intellectual aspects.

The third chapter deals with the 1890s, providing a close analysis of Lynch's Paris writings. It gives a thorough account of the literary and political networks of the Irish diaspora. Lynch's weekly Paris Letter to the Academy shows a heightened engagement and a strong critical view on the often false literary representations of Ireland. The chapter is one of the most complex parts of the book; it constructs an intriguing map of fin-de-siècle social and literary networks. The fourth chapter is dedicated to the mid to late 1890s, a period when Lynch was trying to define her role and engagement with New Woman writing. She was living in Paris, and, in her critical studies, she sought to define a genuine cosmopolitan type of nationalism. According to the authors, her views can be termed transnational, making Lynch a forerunner of contemporary times. The fifth part of the book discusses her travel writings, Lynch having travelled widely in Europe, especially in Greece and Spain. She often wrote and published travelogues, having a special interest in the depiction and figure of the Victorian women traveller. The writers maintain that she has challenged images of the "vagabond" and the woman tourist figure. One is reminded here of Remport's account of Lady Gregory's European travels with Sir William Gregory as part of their Grand Tours of art galleries and collections across continents. Lynch has also given triggering portrayals of the lives of women in the 
countries she visited. The last chapter is devoted to her final book, Autobiography of a Child (1899). It is one of her most well-known pieces, a narrative that challenges the novel genre, and that is full of intertextual references. The study describes this work as one that gathers all the crucial questions of the Lynch oeuvre: the role of women in society, the impacts of gender on identity formation, and the quest of women towards independence and self-expression.

It can be stated that this study is not only an engaging and interesting collection but also an important and missing element from the puzzle that is the tradition of Irish women's writing. The cross-references within the chapters provide an almost pedagogical guidance into the life of Hannah Lynch as well as into the respective historical period. The anecdotes, authentic passages, reviews, and correspondences are harmoniously aligned with the professional critical analysis of the works. Although Lynch died at a very young age, her legacy is now revived in this thoroughly engaging book to prove that she was way more than a "bibliographical curiosity from the sharp end of the $19^{\text {th }}$ century" (p. 5).

Orsolya Szücs

\section{Colin Barr, Ireland's Empire. The Roman Catholic Church in the English- Speaking World, 1829-1914, Cambridge, Cambridge University Press, $2020, \mathrm{xvi}+566 \mathrm{p}$.}

Canadian-born Colin Barr received his $\mathrm{PhD}$ from Cambridge and held academic positions in Ireland and the United States prior to his current post as senior lecturer at the school of divinity, history and philosophy at the University of Aberdeen. His work on Paul Cullen, Archbishop of Dublin (1852-1878) and Ireland's first cardinal (1866), is well known to Irish Studies scholars (Paul Cullen, John Henry Newman, and the Catholic University of Ireland, 1845-1865, Notre Dame, University of Notre Dame Press, 2003). He now offers us a magisterial volume which is poised to become the authoritative study of "Greater Ireland".

Building on his earlier research, Barr presents the rich harvest of his work on new Cullen-related material discovered in Australia in 2004 and on 104 archives scattered across twelve countries on five continents. The organic metaphor applies here: the growth of such a substantial, solid, comprehensive body of work requires an abundance of time - in this case sixteen years. The fruit appears as soon as you delve into the book: the map of Greater Ireland, an ecclesiastical, cultural and political universe structured by the "global Cullenite network" (p. 283), and one that is charted here with a scholarly rigour perfectly balanced with an engaging style laced with dry humour.

The book is divided into seven chapters, each of which is a world in itself with its own dynamics and personalities: the United States, Newfoundland, India, South 